\title{
13: 40138734-40027817
}

National Cancer Institute

\section{Source}

National Cancer Institute. 13:40138734-40027817. NCI Thesaurus. Code C42332.

Physical location of FOXO1A_Gene 